\title{
Effects of Foreign Direct Investment and Human Capital Formation on Labor Market in Manufacturing Sector in Bangladesh
}

\author{
Md. Shakib Hossain ${ }^{1}$, Sabrina Hoque Chowdhury ${ }^{1,2}$, Mallick Rakibul Hasan ${ }^{2}$ \\ ${ }^{1}$ Department of Business Administration, East West University, Dhaka, Bangladesh \\ ${ }^{2}$ School of Business \& Economics, United International University (UIU), Dhaka, Bangladesh \\ Correspondence: Mallick Rakibul Hasan, Senior Lecturer, Department of Business Administration, BGMEA \\ University of Fashion \& Technology (BUFT), S.R Tower, 105 Uttara Model Town, Sector \# 7, Dhaka-1230, \\ Bangladesh. Tel: 880-171-295-0835.E-mail: mallickrakibul@buft.edu.bd
}

Received: August 10, 2015

doi:10.5539/ijbm.v10n10p233
Accepted: September 12, 2015

Online Published: September 18, 2015

URL: http://dx.doi.org/10.5539/ijbm.v10n10p233

\begin{abstract}
Multinational enterprise has the conviction of the concept of globalization is a pictogram of centrifugal process thus MNC always eager to exploit the multitudinous opportunities to disseminate their competitiveness all over the world. For ensuring the competitiveness MNC provides the training to the employees of the host country to acquit about the modern technology and transform the workforce's adroit and incessant progression and engaging continuous innovation and advancement that always cumulating the demand of the skill work forces because there is tapered supply of skill workforces. We make an attempt to assessing the effect of foreign direct investment and human capital formation on labor markets in Bangladesh. We mainly use panel data for 1,689 firms to accomplish the tasks and the tenure is from 2000 to 2014. We observe that FDI which accumulate the wage inequality. We also observe that skill-biased technological changes proliferates wage inequalities. A better framework needs to undertaken and addressing the crisis and strengthen the capabilities of the labor forces and deplete the wage inequalities.
\end{abstract}

Keywords: foreign direct investment, human capital, wages inequalities, labor market

\section{Introduction}

For ensuring the unremitting economic growth and trade competitiveness skill labor forces and foreign direct investment play an inevitable role both for developed and developing country. Macroeconomic variable like income, investment and employment ameliorate due to the inflow of FDI in the host country. FDI has a positive effect on economic growth because foreign MNCs are transferring modern technology and that escalate the efficiency of the host countries labor forces that are significant to establishing the trade competitiveness. Host country with having the accumulation of ambidextrous skill labor forces magnetize a vast amount of technology intensive FDI that ameliorate the economic advancement of a country along with the enhancing the adaptability and capabilities of the workforces. Multinational enterprise (MNE) plays a pivotal role for introduction of new knowledge and wisdom facilities, transferring new technology and information for the host countries. This complementary process gives a hand to expand the capabilities of the domestic entrepreneur along with the interest of the foreign firms.

Structural and counteractive transition of framework completed by the host countries government facilitate the flow of investment from the world, alleviate multitudinous dilemma. Due to the labor inefficiencies always cumulating demand for the skill labor forces in the developing country and that leads to originate gigantic wages disparity. In a country where there is an availability of adroit and competent workforces then there is an accumulation of considerable amount of FDI especially in high value added products. FDI effect the labor market through changes in employment and wage structure of labor forces( Baldwin, 1994) .Most of the developing country has pitiable infrastructure and poor research facility and also the lack of protection of intellectual property rights (patent, copyrights and trade mark). Because of the unavailability of the resources the developing country countenances paramount problems. Due to the conception of the market liberalization policy the developing countries are able to interrelate with the develop countries and through the concept of transferring the modern technology assist to heighten the capacity building approach, thriving technical experience, management knowhow and marketing knowledge. 
Economic advancement arouse opening the economy and enforcing to connected and integrated with the world market and that also proliferate the economic ameliorate of a developing country like Bangladesh. Hence to ensure the incessant economic advancement, Bangladesh needs to ensure and undertaken a distinctive and market oriented policies and proper institutional support and obligatory requires macroeconomic stability. After the engagement of WTO membership Bangladesh continuously adopt the trade reform policies and stimulating and heartening foreign direct investment. Lots of factors are associating to aggregate the FDI from diverse sources like macroeconomic stability, financial market, human capital, infrastructure, market size, capital abundance, agglomeration, geographic location and many more. Because of the technological diffusion and the wave of trade liberalization stimulate the integrated world economy as a single and indispensible unit embedded and accelerated the economic advancement and comprise a commensurate and substantial trade dependence ratio with one to another. Developing country recognize that technological advancement can be possible through foreign direct investment that facilitate economic foster and trade competitiveness.

Michie stated that there are three benefits of human capital accumulation for developing countries to be able to absorb new technologies. First, human capital accumulation leads to higher productivity and profitability as a direct effect. Second, employees are better qualified to absorb and use codified and tacit knowledge. And thirdly, human capital accumulation improves the willingness, commitment and motivation of employees (Michie, 2001).

Higher productivity and better absorbing capacity of modern technology generates the wage disparity among the workers in the host countries. With the substantial flow of FDI assists to upgrade and accelerate the efficiency level of the labor forces in developing country through schooling, training and compelling layoffs. FDI leads human capital formation through upgrading the skills of human capital of host countries by provision off formal training, schooling and spill-over effects of layoffs and turnover of labor force from international firm to domestic firms (Michie, 2001; Kapstien, 2001; Miyamoto, 2003; Ritchie, 2002).

There is no significant research work is accomplished on Foreign Direct Investment (FDI) and human capital formation on labor market in manufacturing sector in Bangladesh. In conclusion we can unambiguously elucidate that FDI might boost the economic competitiveness through export promotion, stimulating investment and advancing linkage. FDI and human capital these are two pivotal associating factors that accelerate the economic competitiveness more if the host country has multitudinous trade competitiveness, gripping competency and constructive financial market. The relation between FDI and human capital has manifold support but the vigorous impacts of FDI on human capital enhancement of the host country are still indistinctive and require further extensive research.

\section{Theoretical Framework}

We follow modification of Katz and Murphy (1992), Velde and Morrissey (2004) to analyze the effects of FDI on relative wages. It can be represented by two factor CES production function with low skilled labor (U) and high skilled labor(S) as two inputs.

$$
\begin{gathered}
f\left(U_{t}, S_{t}\right)=\left\{\lambda\left(\Psi_{U t} U_{t}\right)^{p}+(1-\lambda)\left(\Psi_{s t} S_{t}\right)^{p}\right\}^{1 / p} \ldots \ldots \ldots \ldots \ldots \ldots \ldots \ldots \ldots \ldots \\
\varphi_{u t} \equiv \operatorname{In} \Psi_{u t ;} \varphi_{u t=} \gamma_{1 u}{ }^{t}+\gamma_{2 u}{ }^{f s} ; \varphi_{s t} \equiv \operatorname{In} \Psi_{s t ;} \varphi_{s t}=\gamma_{1 s}{ }^{t}+\gamma_{2 s}{ }^{f s}
\end{gathered}
$$

Where $\varphi_{\mathrm{ut}} \equiv \mathrm{In} \Psi_{\mathrm{ut}}$ and $\varphi_{\mathrm{st}} \equiv \mathrm{In} \Psi_{\mathrm{st}}$ are the functions of labor efficiency units, parameter $p<1$. Labor efficiency index can be interpreted as accumulated human capital. The elasticity of substitution between $\mathrm{U}$ and $\mathrm{S}$ is $\sigma=1 / 1$ $\rho$. Skill base technological transformation may come from with the concentration of FDI. FDI can also make consequence over the labor market. There is wage disparity or inequality. Foreign firms or MNC also come forward for the skill labor forces those who have the prudent and acumen proficiency and comprehensive wisdom about the modern technology and capability to adopt new knowledge.

Demand and supply framework separately effects on wage inequality. Lets supply remain constant always there is a demand for skill labor forces because of diffusion of technology, trade associating factors, factor of productions, location specific advantages, foreign direct investment and availability of knowledge. Labor efficiency indices is a function of share of foreign promoters in equity share $F S$, (T. Velde, 2004) interaction terms $F S_{i t}{ }^{*} \operatorname{train}_{i t}, F S_{i t}{ }^{*}$ royal $_{i t}, F S_{i t} * R n d_{i t}, F S_{i t} * K L_{i t}$ and host of firm level factors as training expenses, royalty expenses, research and development expenses.

Solving for first order condition and keeping marginal productivity equal to factor prices, we derive the formula for relative wages of skilled-unskilled labor.

$$
\operatorname{In}\left(\frac{W s t}{W u t}\right)=\operatorname{In}\left(\frac{1-\lambda}{\lambda}\right)-\frac{1}{\sigma} \operatorname{In}\left(\frac{S t}{U t}\right)+\frac{\sigma-1}{\sigma} \gamma 1 F S_{t}+\varepsilon_{t}
$$


where $\boldsymbol{\gamma}_{1=} \boldsymbol{\gamma}_{1 \mathrm{~s}}+\boldsymbol{\gamma}_{1 \mathrm{u}}$ and $\boldsymbol{\gamma}_{2=} \boldsymbol{\gamma}_{2 \mathrm{~s}}+\boldsymbol{\gamma}_{2 \mathrm{u}}$ thus wage inequality depends on a supply term (relative supply of high to low skilled labor and FDI (foreign shares). The sign of $\boldsymbol{\gamma}_{1}$ directs the effect of FDI on wage inequality. A positive $\gamma_{1}$ leads to increase the wage inequality.

Our equation is mainly comprised with demand and supply. Here the dependent variable is relative wage and the main independent variable is relative employment. This under mentioned equation would symbolize the transform in relative wages of skilled and unskilled labor force being elucidated by differences in skill and unskilled labor force equation.

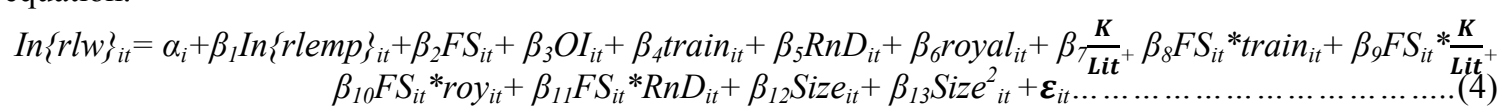

We safely drop relative employment from the equation (4) and constitute a new equation. We constitute our final equation,

$$
\begin{aligned}
& \{r l w\}_{i t}=\alpha_{i}+\beta_{1} F_{i t}+\beta_{2} O I_{i t}+\beta_{3} \text { train }_{i t}+\beta_{4} R_{n} D_{i t}+\beta_{5} r \operatorname{ryal}_{i t}+\beta_{6} \frac{K}{\text { Lit }^{+}}+\beta_{7} F S_{i t}{ }^{*} \operatorname{train}_{i t}+\beta_{8} F S_{i t} * \frac{K}{L i t}+\beta_{9} F S_{i t}{ }^{*} \text { roy }_{i t}+ \\
& \beta_{10} F S_{i t} * R n D_{i t}+\beta_{11} \text { Size }_{i t}+\beta_{12} \text { Size }_{i t}{ }_{i t}+\varepsilon_{i t}
\end{aligned}
$$

Here $\{r l w\}_{i t}=$ relative price of labor, ratio of skilled to unskilled labor force in firms, $F S_{i t}=$ equity share of foreign promoters in firms, $O I_{i t}=$ Total forex earnings + Total forex spending/ Total Income, Openness Index of firms ; Train $_{i t}=$ training expenses by firms on their employees; $R n D_{i t=}$ Research and Development expenses by the firms; royal ${ }_{i t}=$ royality expenses by firms; $\frac{K}{L i t}=$ Gross Fixed assets/ number of employees of firms; $F S_{i t}{ }^{*}$ train $_{i t=}$ Interaction Term1,FS *Training expenses by the firms, $F S_{i t}{ }^{* K}$ Lit $=$ Interaction Term 2,FS*CapitalLabor ratio of the firms, $F S_{i t}{ }^{*}$ roy $_{i t}=$ Interaction Term 3,FS*Royalty expenses by the firms; $F S_{i t}{ }^{*} R n D_{i t}=$ Interaction Term 4,FS* Research and Development, Size $e_{i t}=$ Size of firms, $\quad$ Size $_{i t}{ }_{i t}=$ Size $_{i t}{ }^{*}$ Size $_{i t}$ of the firms.

\begin{tabular}{|c|c|}
\hline Description of The variables & Sign \\
\hline $\multicolumn{2}{|l|}{r l w}_{i t}=$ relative price of labor, ratio of skilled to unskilled labor force in firms \\
\hline$F S_{i t}=$ equity share of foreign promoters in firms & $(+)$ \\
\hline$O I_{i t}=$ Total forex earnings + Total forex spending/Total Income, Openness Index of firms & $(-)$ \\
\hline Train $_{i t}=$ training expenses by firms on their employees & $(-)$ \\
\hline$R n D_{i t}=$ Research and Development expenses by the firms & $(+)$ \\
\hline royal $_{i t}=$ royality expenses by firms & $(-)$ \\
\hline$\frac{K}{\text { Lit }}=$ Gross Fixed assets $/$ number of employees of firms & $(+)$ \\
\hline \multicolumn{2}{|l|}{ Interaction items } \\
\hline$F S_{i t}{ }^{*}$ train $_{i t}$ Interaction Term 1,FS *Training expenses by the firms & $(+)$ \\
\hline$F S_{i t} * \frac{K}{L i t}=$ Interaction Term $2, F S^{*}$ Capital- Labor ratio of the firms & $(-)$ \\
\hline$F S_{i t}{ }^{*}$ roy $_{i t}=$ Interaction Term $3, F{ }^{*}$ Royalty expenses by the firms & $(+)$ \\
\hline$F S_{i t} * R n D_{i t}=$ Interaction Term $4, F S^{*}$ Research and Development & $(-)$ \\
\hline Size $_{i t}=$ Size of firms & $(+)$ \\
\hline Size $_{i t}^{2}=$ Size $_{i t}{ }^{*}$ Size $_{i t}$ of the firms. & $(-)$ \\
\hline
\end{tabular}

On the bases of the equation (5) we assume that the following variable exhibits the following expected signs.

Table 1. Expected sign of the different variables

\section{Data Sources}

For accomplishing the empirical tasks we using the both public and private manufacturing firms in Bangladesh. The economy in Bangladesh is continuously accelerated and integration with the international market is amplifying. According to the report of Ministry of finance and commerce the highest percentage of FDI flow in the manufacturing sector and it increasing very rapidly. Manufacturing sector is growing in a rapid way. Because of the trade liberalization policies and establishing commensurate environment stimulates foreign direct investment in manufacturing sector in Bangladesh. For conducting the research tasks we using random sample method. The total sample is 1,689 for this task. The industries included Food (247), Textile (523), Chemicals 
(245), Construction materials (67), Consumer goods (145), Machinery and Machine tools (175), Mining (35), Transport Equipment (135), Communication (15), Construction and real estate (41) and Miscellaneous Manufacturing (61).

\section{Result}

For analyzing the equation (5) we include the factors that causing changes in relative wages like foreign share, openness index, capital-labor ratio and firm specific factors as training expenses, royalties expenses, expenses on research and development, size and square term of size of the firms. We also use four different interaction terms to test the probable consequences of FDI and human capital formation on relative wages. Our interaction terms include interaction between foreign direct investment and training, royalties, research and development and capital-labor ratio.

Table 2. Fixed effect estimation (2000-2014): dependent variable relative wages

\begin{tabular}{|c|c|c|c|c|c|c|}
\hline & 1 & 2 & 3 & 4 & 5 & 6 \\
\hline & $0.02 * * *$ & $0.12 * * *$ & $0.08 * * *$ & $0.23 * * *$ & $0.45 * * *$ & $0.21 * * *$ \\
\hline \multirow[t]{2}{*}{ Lnrlemp } & $(0.02)$ & $(0.03)$ & $(0.01)$ & $(0.02)$ & $(0.03)$ & $(0.02)$ \\
\hline & $4.51 \mathrm{E}-06^{*}$ & $6.15 \mathrm{E}-07$ & $5.77 \mathrm{E}-012 *$ & $3.27 \mathrm{E}-04 *$ & $2.00 \mathrm{E}-03$ & $2.75 \mathrm{E}-04$ \\
\hline \multirow[t]{2}{*}{ foreignshare } & $(1.36 \mathrm{E}-02)$ & $(1.09 \mathrm{E}-04)$ & $(6.61 \mathrm{E}-02)$ & $(2.47 \mathrm{E}-02)$ & $(1.45 \mathrm{E}-03)$ & $(1.52 \mathrm{E}-03)$ \\
\hline & & & 0.65 & & & \\
\hline \multirow[t]{2}{*}{ Train } & -0.33 & -0.21 & $(0.88)$ & -0.32 & -0.0238 & -0.321 \\
\hline & & & $1.44 \mathrm{E}-03 * * *$ & $0.05 * * *$ & $0.05^{*}$ & $0.01^{*}$ \\
\hline \multirow[t]{2}{*}{$\mathrm{Kl}$} & & & $(3.72 \mathrm{E}-04)$ & $(1.36 \mathrm{E}-03)$ & $(2.35 \mathrm{E}-03)$ & $(0.05)$ \\
\hline & & & & & $2.11 \mathrm{E}-05^{* * *}$ & \\
\hline \multirow[t]{2}{*}{ Openness } & & & $-7 \mathrm{E}+21$ & $-2 \mathrm{E}+37$ & $(3.41 \mathrm{E}-01)$ & \\
\hline & & & & 1.4639 & & 1.293 \\
\hline \multirow[t]{2}{*}{ Rnds } & & & & $(1.69)$ & & $(2.37)$ \\
\hline & & & & & $-4.52 * * *$ & -2.46 \\
\hline \multirow[t]{2}{*}{ Roys } & & & & & $(1.61)$ & $(2.11)$ \\
\hline & $5.68 \mathrm{E} 0.6^{* * *}$ & $2.42 \mathrm{E}-06^{*}$ & $2.91 \mathrm{E} 05^{* * *}$ & $2.00 \mathrm{E}-05 * * *$ & $5.37 \mathrm{E}-06$ & 4.29E- $06 * * *$ \\
\hline \multirow[t]{2}{*}{ Fditrain } & $(1.23 \mathrm{E}-06)$ & $(2.93 \mathrm{E}-06)$ & $(2.42 \mathrm{E}-06)$ & $(1.38 \mathrm{E}-06)$ & $(1.51 \mathrm{E}-06)$ & $(1.77 \mathrm{E}-06)$ \\
\hline & & & & & $0.21 * *$ & 0.12 \\
\hline \multirow[t]{2}{*}{ Fdiroy } & & & & & $(0.05)$ & $(0.05)$ \\
\hline & & & & -0.03 & & -0.11 \\
\hline \multirow[t]{2}{*}{ Fdirnd } & & & & $(0.02)$ & & $(0.06)$ \\
\hline & & & $2.31 \mathrm{E}-05^{*}$ & $-2.784 \mathrm{E}-04 * *$ & $-2.41 \mathrm{E}-03$ & $-2.11 \mathrm{E}-04 * *$ \\
\hline \multirow[t]{2}{*}{ Fdikl } & & & $(2.333 \mathrm{E}-05)$ & $(2.68 \mathrm{E}-04)$ & $(2.54 \mathrm{E}-04)$ & $(1.98 \mathrm{E}-04)$ \\
\hline & $4.65 \mathrm{E}-06^{* * *}$ & $2.35 \mathrm{E}-06^{*}$ & & & & \\
\hline \multirow[t]{2}{*}{ Size } & $(2.11 \mathrm{E}-07)$ & $(3.29 \mathrm{E}-06)$ & & & & \\
\hline & $-1.21 \mathrm{E} 12 * * *$ & $-1.67 \mathrm{E}-3 * *$ & & & & \\
\hline \multirow[t]{2}{*}{ Size $^{2}$} & $(4.11 \mathrm{E}-12)$ & $(3.29 \mathrm{E}-12)$ & & & & \\
\hline & $0.11 * * *$ & $0.08 * * *$ & $0.11 * * *$ & $0.07 * * *$ & $0.11 * * *$ & $0.12 * * *$ \\
\hline \multirow[t]{2}{*}{ Time dummy } & $(0.01)$ & $(0.01)$ & $(0.01)$ & $(0.01)$ & $(0.01)$ & $(0.01)$ \\
\hline & $1.31 * * *$ & $1.34 * * *$ & $1.42 * * *$ & $2.77 * * *$ & $2.22 * * *$ & $2.51 * * *$ \\
\hline Constant & $(0.11)$ & $(0.11)$ & $(0.11)$ & $(0.15)$ & $(0.10)$ & $(0.11)$ \\
\hline Observation & 645 & 527 & 521 & 425 & 325 & 371 \\
\hline
\end{tabular}

From the Table 1, we can observe that foreign share is found to be positive and significantly causes to wage inequality. Many developing countries face shortages in domestic savings, trade imbalances and a foreign exchange crisis. It is assumed that in the absence of foreign capital, the shortages of external financing are likely to put constraints on the economic growth and living conditions of the people. It is claimed that failing to attract foreign capital implies that national income and living standards will be negatively affected.

In column 1, 3 and 4 is found that foreign share is positive and significantly related to wage inequality though the effect is not big. Training expenses are negatively but insignificantly related to relative wages on their employees. The possible explanation of this cause because of training that depletes the gap between demand and supply. MNC provide the extensive amount of training and transferring knowledge that assists to strengthen the 
adaptability and competency of the labor forces and that apparently bridge the gap of paucity of the skill workforces. The coefficient of capital -labor ratio is also observed to be positive and significant from column 3 , 4,5 and 6 . One unit increase in capital -labor ratio increase wage inequality by approximately 2 units. Any transitions of technology facilitate of transferring new knowledge and require for new skills that augment the wage inequality. The coefficient of openness has significant but indistinctive consequence on relative wages. The possible explanation is Due to the trade openness the economic growth stemming, escalate specialization by transferring technology and diversifying the production facility with the assists of globalization of production that accelerate the productivity and amplify the export capacity.

The WTO led elimination of the transient policy imposed trade restrictions are expected to promote the efficient utilization and allocation of both imported and domestic resources, engendering competition that can promote an environment conducive for specialization and scale economies. The coefficient of research and development is found positive but insignificant impact on wage inequality. The coefficient of royalty is found out to be negatively significant for all the specification. Size of the firms is significantly related to wage inequality because there is massive gap between the MNC and indigenous firms in terms of size, capacity, technology, research facilities and capital. It is indubitably predicted that when the gigantic foreign firms operating the business in the host country it causes the wage inequality. The other terms square of size is negative that implies after certain level size may reduce the wage inequality and the possible explanation is like that due economic scale, experience curve and location economy can make this things.

Now we interpret and interest in coefficients of interaction terms. The interaction between foreign direct investment and training expenses seems to be positive and significant on wage inequality. FDI is positively associated with economic growth. Low level of human capital increases wages inequality. The coefficient of interaction terms of foreign direct investment and royalty payment is also exploiting to be significant and positive. The interaction terms of FDI and capital-labor ratio is also find out negative and significant, the possible explanation is that FDI assist to transferring technology that escalate the knowledge and skills of the local workers and decelerate the wages disparity. The interaction of FDI and research and development is also found negative and insignificant on wages inequality.

We also go through the Maximum likelihood method to observe whether there is any inconsistency.

Table 3. Maximum likelihood method (2000-2014): dependent variable relative wages

\begin{tabular}{|c|c|c|c|c|c|c|}
\hline & 1 & 2 & 3 & 4 & 5 & 6 \\
\hline Lnrlemp & $\begin{array}{l}0.22 * * * \\
(0.01)\end{array}$ & $\begin{array}{l}0.41 * * * \\
(0.02)\end{array}$ & $\begin{array}{l}0.31 * * * \\
(0.01)\end{array}$ & $\begin{array}{l}0.12 * * * \\
(0.02)\end{array}$ & $\begin{array}{l}0.35^{* * *} \\
(0.03)\end{array}$ & $\begin{array}{l}0.31 * * * \\
(0.03)\end{array}$ \\
\hline $\begin{array}{l}\text { Foreign } \\
\text { share }\end{array}$ & $\begin{array}{l}1.21 \mathrm{E}-03 * * * \\
(6.11 \mathrm{E}-04)\end{array}$ & $\begin{array}{l}1.22 \mathrm{E}-03 * * * \\
(6.41 \mathrm{E}-04)\end{array}$ & $\begin{array}{l}1.39 \mathrm{E}-03 * * * \\
(5.21 \mathrm{E}-04)\end{array}$ & $\begin{array}{l}1.72 \mathrm{E}-03 * * * \\
(4.33 \mathrm{E}-03)\end{array}$ & $\begin{array}{l}1.61 \mathrm{E}-03 * * * \\
(3.41 \mathrm{E}-03)\end{array}$ & $\begin{array}{l}1.31 \mathrm{E}-03 * \\
(3.43 \mathrm{E}-03)\end{array}$ \\
\hline Train & -0.29 & 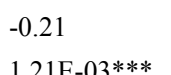 & -0.23 & $\begin{array}{l}-0.32 \\
0.07 * * *\end{array}$ & $-0.35 * *$ & $-0.21 * * *$ \\
\hline $\mathrm{Kl}$ & & $(2.56 \mathrm{E}-04)$ & & (3.11E-03) & $\begin{array}{l}(2.21 \mathrm{E}-03) \\
1.33 \mathrm{E}-05^{* * *}\end{array}$ & $(2.31 \mathrm{E}-01)$ \\
\hline Openness & & $-2 \mathrm{E}+81$ & & $\begin{array}{l}-2.6 \mathrm{E}+33 \\
0.51\end{array}$ & $(2.11 \mathrm{E}-06)$ & 0.33 \\
\hline Rnd & & & & $(0.24)$ & & $(2.66)$ \\
\hline Royality & & & & & -1.412 & -2.718 \\
\hline Fditrain & $\begin{array}{l}2.11 \mathrm{E}-06 * * * \\
(1.23 \mathrm{E}-06)\end{array}$ & $\begin{array}{l}2.66 \mathrm{E}-05 * * * \\
(2.19 \mathrm{E}-06)\end{array}$ & $\begin{array}{l}2.10 \mathrm{E}-06 \\
(3.54 \mathrm{E}-06)\end{array}$ & $\begin{array}{l}2.51 \mathrm{E} 06 * * * \\
(2.33 \mathrm{E}-06)\end{array}$ & $\begin{array}{l}2.81 \mathrm{E}-06 * * * \\
(1.61 \mathrm{E}-06) \\
0.03 *\end{array}$ & $\begin{array}{l}2.51 \mathrm{E} 06 * * * \\
(2.49 \mathrm{E}-06)\end{array}$ \\
\hline Fdiroy & & & & & $(0.04)$ & $-2 \mathrm{E}+27$ \\
\hline Fdirnd & & $2.41 \mathrm{E}-05$ & & -0.02 & & -0.05 \\
\hline Fdikl & & $(1.33 \mathrm{E}-05)$ & & $-4 \mathrm{E}+55$ & $-4 \mathrm{E}+11$ & $-4 \mathrm{E}+12$ \\
\hline Size & $\begin{array}{l}1.33 \mathrm{E}-06^{* * *} \\
(3.57 \mathrm{E}-07)\end{array}$ & & $\begin{array}{l}1.27 \mathrm{E}-06 * * * \\
(2.08 \mathrm{E}-07)\end{array}$ & & & \\
\hline Size $^{2}$ & $-2.5115 \mathrm{E}-19$ & $-2.4172 \mathrm{E} 25$ & & & & \\
\hline
\end{tabular}




\begin{tabular}{lllllll}
\hline Time & $0.11 * * *$ & $0.12 * * *$ & $0.12 * * *$ & $0.12 * * *$ & $0.11 * * *$ & $0.12 * * *$ \\
dummy & $(0.01)$ & $(0.01)$ & $(0.01)$ & $(0.01)$ & $(0.01)$ & $(0.02)$ \\
& $2.11 * * *$ & $2.18 * * *$ & $2.31 * * *$ & $2.15 * * *$ & $2.16 * * *$ & $(0.11)$ \\
Constant & $(0.11)$ & $(0.12)$ & $(0.12)$ & $(0.12)$ & & $-129 * .54131$ \\
Log & & & & -216.56891 & -102.12293 \\
Likeihood & -222.35229 & -425.21121 & -315.22950 & 425 & 325 & 371 \\
Observation & 645 & 527 & 521 & & & \\
\hline
\end{tabular}

Foreign share is found to be positive and significantly causes to wage inequality. The other coefficient training expenses are negatively but insignificantly related to relative wages on their employees except the column 5 and 6 . The coefficient of capital-labor ratio is positive and significantly causes wage inequality. The other coefficient of openness is negative but significantly effect on wage inequality. Research and development is positively effect of exploring new knowledge but it is not significantly effect on wage inequality. Although in column 5 the coefficient of royalty is find out negative but significantly effect on wage inequality but in column 6 it make positive but insignificantly effect on wage inequality. The interaction between foreign direct investment and training expenses seems to be positive and significant on wage inequality in every model except column 3 . The coefficient of interaction terms of foreign direct investment and royalty payment is also found to be significant and positive. On the other hand the interaction terms of FDI and capital-labor ratio is found out negative and significant. The interaction of FDI and research and development is also found negative and insignificant on wages inequality.

\section{Conclusion}

The relation between the FDI and human capital is highly linear and multiple equilibrium. From last couple of years in Bangladesh, there is unremitting flow of FDI in manufacturing sector and we explore that there is significant wage inequality among the workers. Due to the globalization, there is a greater income inequalities and proliferate unemployment in developing countries because of low technical skills, poor human capital formation and lack of adaptability of technological changes. Proper institutional support of the developing country and coordination of the different agencies need to constitute for the acceleration of the efficiency level of the work forces of the developing country. Bangladesh needs to adopt trade openness policies because it stemming economic advancement and enhance specialization and human capacity building by transferring technology and ensure export diversification and ultimately alleviate wages disparity. Imbalance between demand and supply of skill labor forces is one of the major reasons for wages disparity. Poor technical support and inefficacious research and development agenda makes a negative consequence on forming human capital in Bangladesh. Developed country needs to consider regarding the subject matter of human capital formation in developing country. Developed country not just concentrate for market expansion rather should also need to passionately concentrate on the capacity building and providing financial aid to augment the human skills that are necessarily require in a competitive world. So in conclusion we can say that the disparity needs to address and aggregating substantial and commensurate policies need to undertaken for the purpose of eradicating this imbalance to strengthen the economy and ensuring the sustainable trade competitiveness and fostering the macroeconomic stability.

\section{References}

Baldwin, E. R. (1994). Effects of Trade and Foreign Direct Investment on Employment and Relative Wages. OECD Economic Studies, 23.

Kapstein, E. B. (2002). Virtuous Circles? Human Capital Formation, Economic Development and the Multinational Enterprise. OECD Development Centre Working Paper No. 191.

Katz, Lawrence, F., \& Murphy, K. M. (1992). Changes in Relative Wages, 1963-1987: Supply and Demand Factors. The Quarterly Journal of Economics, 7(1), 35-78. MIT Press.

Michie, J. (2001). The Impact of Foreign Direct Investment on Human Capital Enhancement in Developing Countries. Review from http://www.oecd.org/dev/2731643.pdf

Miyamoto, K. (2003). Human Capital Formation and Foreign Direct Investment in Developing Countries. OECD Development Centre Working Paper No. 211.

Ritchie, B. K. (2002). Foreign Direct Investment and Intellectual Capital Formation in Southeast Asia. OECD Development Center Working Paper No 194. 
Velde, D. T., \& Morrissey, O. (2004). Foreign Direct Investment, skills and wage inequality in East Asia. Journal of the Asia Pacific Economy, 9(3).

\section{Copyrights}

Copyright for this article is retained by the author(s), with first publication rights granted to the journal.

This is an open-access article distributed under the terms and conditions of the Creative Commons Attribution license (http://creativecommons.org/licenses/by/3.0/). 